\title{
15: 77024475-77001162
}

National Cancer Institute

\section{Source}

National Cancer Institute. 15: 77024475-77001162. NCI Thesaurus. Code C42022.

Physical location of CTSH_Gene 